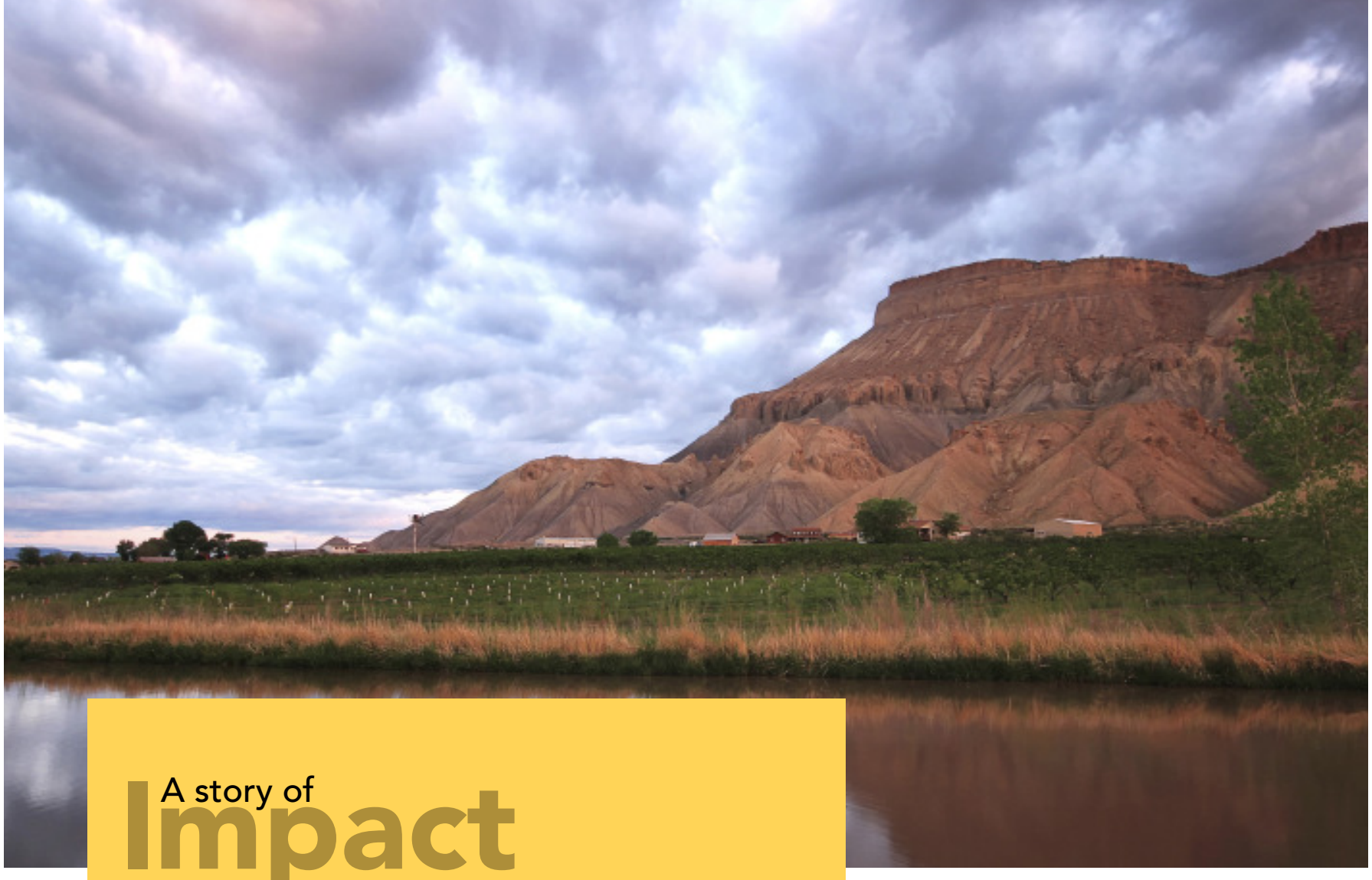

\section{Use of Model Farmers Proves Effective in Increasing Safety Practices Among Navajo Agricultural Workers}

Covering 27,000 square miles in Arizona, New Mexico, and Utah, the Navajo Nation, geographically, is the largest American Indian reservation in the U.S. ${ }^{7}$ Within the Navajo Nation, many use farming for personal means including food, business, and trade. Of the greater than 12,000 acres of irrigable land, fewer than 5,000 acres are being farmed due to water shortages and financial strain. ${ }^{5}$ In order to increase the yield potential of the land being used, the use of pesticides and growth agents is vital. A study by the California Department of Pesticide Regulation found that agricultural workers represented 93\% of pesticide poisoning cases from $1998-2001 .^{6}$

The Southwest Center for Agricultural Health, Injury Prevention and Education - funded by the National Institute for Occupational Safety and Health (NIOSH) - addressed these important topics with its Model Farmer Dissemination Project from 2006-2011. This research was developed by Dr. Deborah Helitzer-a researcher from the University of New Mexico-in collaboration with cooperative extension services from the University of Arizona and New Mexico University; the Navajo Nation Departments of Health, Agriculture, and Environmental
- Agricultural expanse in the Western United States. Photo by Thinkstock.

Relevant Information

The Model Farmer Dissemination project serves as a continuation of the Navajo Nation Evaluation - a program designed to increase the safety $\&$ welfare of agricultural workers in the Navajo Nation.

EPA's Current Agricultural Worker

Protection Standard is a regulation

aimed at reducing the risk of pesticide poisoning \& injury among agricultural workers \& pesticide handlers. ${ }^{2}$

The $>\mathbf{2}$ million agricultural workers $\&$ pesticide handlers who work at $600,000+$ agricultural establishments are protected under the Current Agricultural Worker Protection Standard. ${ }^{2}$

\section{$f\left(\mathbb{C}_{3}\right.$}

Follow NIOSH on Facebook and Twitter Sign up for eNews at cdc.gov/niosh/enews 
Health; the Indian Health Service; and the Navajo Nation Farm Board, Water Board, and Human Research Review Board. This intervention specifically targeted pesticide safety and education for handling chemicals, understanding their uses, interpreting labels, proper procedures for applying pesticides, and general knowledge about how to use integrated pest management (IPM) to increase overall agricultural yield. "Model Farmers"- those viewed as trusted community members-were trained by agricultural extension agents to provide hands-on learning experiences to community farmers.

Impact

Within the participating communities of 120 farm families (average family size for Navajo Nation is 4 persons), ${ }^{1}$ significant changes were observed in pesticide use, storage behaviors, and safety and pesticide application technique during the five year study. The use of locked storage practices for pesticides increased from $60 \%$ to $94 \%$. The use of safety equipment increased from $43 \%$ to $100 \%$. The use of application equipment increased from $23 \%$ to $60 \%$. Findings also showed agricultural yield increased in correctly treated plots up to $56 \%$ in corn ears and $41 \%$ in alfalfa when compared with control plots. ${ }^{3}$ In addition to the hands-on training by Model Farmers, workshops were offered during Shiprock Ag Days, an annual program run by the Shiprock cooperative extension service.

The 120 farmers who participated in this research are sufficiently well prepared to train other farmers on correct pesticide safety measures, which have proven to also increase farm yields. Given that farmers in these communities learn from their neighbors and family members, the training of these Model Farmers has significant potential to advance the workplace practices of Navajo agricultural workers, and improve the health and safety of these workers and their families.

More information on agriculture-related topics can be on the NIOSH website (www.cdc.gov/niosh) or by visiting the Southwest Center for Agricultural Health, Injury Prevention and Education (www.swagcenter.org/projectspast.asp). Information specific to the Model Farmer Dissemination Project may be found in the Journal of Ag Safety and Health 20(3):175-198—Culturally Relevant Model Program to Prevent and Reduce Agricultural Injuries—by Helitzer DL, Hathorn G, Benally J, and Ortega C.

1-7 For a complete list of references, see www.cdc.gov/niosh/docs/2015-177/.

\section{SAFER - HEALTHIER PEOPLE $^{\text {TM }}$}

U.S. Department of Health and Human Services

Centers for Disease Control and Prevention

National Institute for Occupational Safety and Health

To receive NIOSH documents or more information about occupational safety and health topics, please contact NIOSH.

Telephone: 1-800-cdc-info (1-800-232-4636) | TTY: 1-888-232-6348 | www.cdc.gov/info.

For a monthly update on news at NIOSH, subscribe to NIOSH eNews by visiting www.cdc.gov/niosh/eNews.

DHHS (NIOSH) Publication No. 2015-177.

November, 2014.
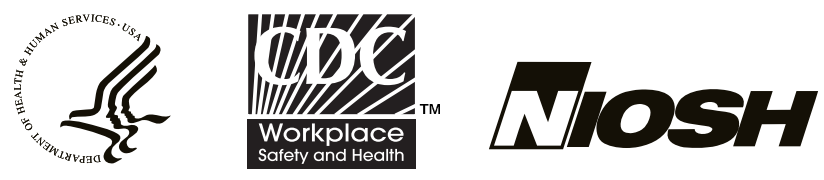